HUMANIKA Vol. 23 No.1 (2016) ISSN 1412-9418

Implementasi Semangat Persatuan Pada Masyarakat Multikultural Melalui Agenda Forum Kerukunan Umat Beragama (Fkub) Kabupaten Malang

Nasrul Wahyu Suryawandan, Endang Danial

\title{
IMPLEMENTASI SEMANGAT PERSATUAN PADA MASYARAKAT MULTIKULTURAL MELALUI AGENDA FORUM KERUKUNAN UMAT BERAGAMA (FKUB) KABUPATEN MALANG
}

\author{
Oleh : \\ ${ }^{1}$ Nashrul Wahyu Suryawandan ${ }^{2}$ Endang Danial \\ ${ }^{1}$ Mahasiswa Pendidikan Kewarganegaraan SPs Universitas Pendidikan Indonesia \\ ${ }^{2}$ Dosen Departemen Pendidikan Kewarganegaraan SPs Universitas Pendidikan Indonesia \\ E-mail: endangdanial@gmail.com
}

\begin{abstract}
The background of this research is the social diversity of Indonesian people. This situation causes conflicts among Indonesian people which need solutions to minimilize the effects of the conflict among the society. The study over the value of unification and harmony of the Religious Community Forum is one of the implementation of the unification spirit, the aspect of toleration, which needs to be spread out among the society. The goal of this research is to dig down how the Religious Community Forum works in increasing the Malang multicultural society understanding over the value of unification. It is also to know how the Religious Community Forum increases the society toleration and the importance of unification among Malang society diversity. Alt last but not least, the study over the unification value functions as a report of how the Religious Community Forum maintain the Indonesian people unification. This research use subjects of the Religious Community Forum members, religion leaders, government officers, and Malang people. The approach used in this research is qualitative with case study method. The data collection techniques used in this study are observation, interview, documentation, and participation. Meanwhile, the data is analyzed by using data reduction, data display, and verivication.The findings of this research are: 1) The activities done by the Religious Community Forum contain the unification value; the unification and harmony religious communities, conflicts and dialogues counseling, toleration, socialization over the government policy of the unification and harmony of diverse society; 2)The Religious Community Forum contains social aspects; the diversity value, toleration, pluralism, and the society unification, which can be descended to the next generation; 3) The forum has some roles in maintaining and keeping the unification value of multicultural society through the activities applied in the society. Malang government supports and coordinates any institution works in society unification and harmony. The actions taken shows that the government are concerned on the unification of multicultural society. Thus, it can be concluded that the activities done by the Religious Community Forum of Malang contain the unification value.
\end{abstract}

Key words: Unification, multicultural society, Religious Community Forum. 


\section{PENDAHULUAN}

\subsection{Latar Belakang}

Bangsa Indonesia merupakan bangsa yang terdiri dari masyarakat yang majemuk, multikultur serta terdiri dari berbagai agama dan keyakinan. Keberagaman yang dimiliki oleh bangsa Indonesia merupakan suatu nilai positif yang memerlukan perhatian khusus agar hal tersebut mampu menjadi sumber kekuatan dan ciri khas bangsa Indonesia di dunia internasional. Menurut Poespowardjojo(1991: 51) "Selanjutnya kita ketahui, kondisi masyarakat sejak permulaan hidup kenegaraan adalah serba majemuk. Masyarakat Indonesia bersifat multi etnis, multi religius dan multi ideologis. Kemajemukan tersebut menunjukkan adanya berbagai unsur yang saling berinteraksi. Berbagai unsur dalam bidang-bidang kehidupan masyarakat merupakan benih-benih yang dapat memperkaya khasanah budaya untuk membangun bangsa yang kuat...”. Sementara itu menurut Muzhar(Harahap 2007: 28). Multikulturalisme mencakup gagasan, cara pandang, kebijakan, penyikapan dan tindakan, oleh masyarakat suatu negara, yang majemuk dari segi etnis, budaya, agama dan sebagainya, namun mempunyai cita-cita untuk mengembangkan semangat kebangsaan yang sama dan memmpunyai kebanggaan untuk mempertahankan kemajemukan tersebut.

Menurut Octaviani (2013:113) prinsip-prinsip dasar multikulturalisme mengakui dan menghargai keberagaman kelompok masyarakat seperti etnis, ras, budaya,gender,stratasosial,agama,perbeda an kepentingan, keyakinan dan tradisi yang

akansangatmembantubagiterwujudnyaper ubahan format perilaku sosial yang kondusifdanditengahkehidupanmasyaraka t yang majemuk, sedangkan menurut Azra (dalam Budimansyah dan Suryadi 2008: 43) multikulturalisme adalah landasan budaya yang terkait dengan pencapaian civility (keadaban) yang amat esensial bagi terwujudnya demokrasi yang berkeadabandan keadaban yang demokratis. Multikulturalisme merupakan sebuah landasan budaya yang bertujuan untuk tercapainya keadaban yang kemudian berhubungan dengan terwujudnya demokrasi yang berkeadaban.

Keberagaman yang terdapat pada masyarakat Indonesia merupakan identitas yang menjadi ciri khas dari bangsa lain di dunia. Pembentukan keragaman dalam masyarakat tidak dapat dipisahkan dari adanya perkembangan dalam hal informasi dan komunikasi yang berdampak pada banyaknya kelompokkelompok baru dalam masyarakat yang tubuh dari pertukaran budaya melalui informasi dan komunikasi. Kelompokkelompok tersebut hidup pada satu wilayah Indonesia serta mendapatkan pengakuan dari pemerintah dalam daerah tersebut. Selanjutnya,Parekh (2000: 3)mengatakan bahwa keragaman komunal yang muncul bila terdapat anggotaanggota masyarakat yang hidup dalam kelompok-kelompok yang terorganisir dengan baik dan berbagi sistem dan praktik kehidupan tertentu yang berbeda dari masyarakat pada umumnya, misalnya pada kelompok-kelompok keagamaan baru, kelompok etnis atau imigran yang hidup di wilayah tertentu.

Dengan adanya keberagaman tersebut diperlukan adanya penghayyatan dan implementasi sikap toleransi antar masyarakat untuk menjaga persatuan dan kesatuan bangsa Indonesia serta menjaga menjaga perdamaian, keharmonisan hidup bermasyarakat sekaligus meminimalisir potensi konflik pada masyarakat. Muchali (2013: 4) menyatakan bahwa toleransi, (Arab) berarti batas ukur untuk penambahan atau pengurangan yang masih diperbolehkan. Pemahaman terhadap toleransi sangat penting dalam 
usaha membangun masyarakat yang damai, dan penuh kasih, lebih-lebih masyarakat yang multikultural.Dalam masyarakat multikultur seperti Indonesia gerakan dialog antaragama harus ditopangkan oleh toleransi kultural, yakni tata laku kehidupan. Ia bukan sematamata didasarkan pada toleransi antarkeberimanan, namun seyogyanya dibingkai dalam toleransi antarkemanusiaa. Bukan hanya toleransi dalam pengertian pasif, akan tetapi toleransi aktif yaitu kesediaan untuk secara aktif menghormati, mengakui dan secara partisipatif membagun perdamaian. Sementara itu, Susanto(2006: 47) berpendapat bahwa pluralismeberpandangan bahwa secarateologis pluralitas(keragaman) agamamerupakan realitas niscayayangmasing-masingberdiri sejajarsehinggasemangatmissionaris(dakw ah)dianggap tidakrelevan.

Munculnya berbagai kelompokkelompok baru dan adanya realitas masyarakat Kabupaten Malang yang terdiri dari berbagai etnis, suku, agama dan ras yang berbeda mendorong adanya semangat persatuan untuk tetap memiliki jiwa dan semangat nasionalisme keindonesiaan. Semangat dan kemauan dari setiap kelompok untuk tetap bersatu dalam konteks Negara Kesatuan Republik Indonesia (NKRI) merupakan salah satu modal utama dalam mencapai cita-cita dan tujuan bangsa Indonesia. Menurut Darmodiharjo (1991: 42) persatuan Indonesia adalah persatuan bangsa yang mendiami wilayah Indonesia. Bangsa yang mendiami wilayah Indonesia ini bersatu karena didorong untuk mencapai kehidupan kebangsaan yang bebas dalam wadah negara yang merdeka dan berdaulat. Persatuan Indonesia merupakan faktor yang dinamis dalam kehidupan bangsa Indonesia, bertujuan memajukan kesejahteraan umum, dan mencerdaskan kehidupan bangsa serta ikut mewujudkan perdamaian dunia yang abadi. Sementara itu, menurut Poespowardjojo (1991: 51)salah satu peranan Pancasila yang menonjol sejak permulaan penyelenggaraan Negara Republik Indonesia adalah fungsinya dalam mempersatukan seluruh rakyat Indonesia menjadi bangsa yang berkepribadian dan percaya pada diri sendiri.

Realitas yang di hadapi dalam mqasyarakat Kabupaten Malang antara lain, adanya keberagaman soasial masyarakat dalam konteks agama, kebudayaan, etnis dan golonganpada masyarakat. Dengan adanya realitas tersebut muncul dampak negative yaitu adanya sikap fanatisme dan munculnya konflik antar kelompok agama terkait dengan pendirian rumah ibadah dalam masyarakat Kabupaten Malang, sehingga mengancam nilai-nilai persatuan yang telah ada pada masyarakat yang dapat dilihat dari adanya kebersamaan dalam melakukan peribadahan, doa bersama, kerjasaa dalam lingkup sosial kemasyarakatan dan adanya kerukunan antar individu dalam masyarakat Selanjutnya adalah memudrnya nilai perstuan dan kesatuan dalam lingkup daerah Kabupaten Malang yang selanjutnya akan mengancam nilai persatuan dan kesatuan pada lingkup nasional bangsa Indonesia. Hingga pada akhirnya, penelitian ini dianggap perlu untuk dikaji dalam aspek sosial masyarakat Kabupaten Malang dalam membentuk dan membangun nilai-nilai persatuan pada maasyarakat yang multikultur bangsa Indonesia.Oleh karena itu, perlunya sebuah tulisan mengenai pengembangan nilai persatuan pada masyarakat multikultur. Hal demikian menarik untuk meneliti tentang Semangat Persatuan pada masyarakat Multikultural melalui agenda Forum Kerukunan antar Umat beragama di Kabupaten Malang. 


\subsection{Metode Penelitian}

Penelitian ini menggunakan pendekatan kualitatif dengan metode studi kasus untuk memaknai interaksi antara anggota Forum Kerukunan Umat Beragama Kabupaten Malang dengan realitas pengembangan nilai-nilai multikulturalisme dan toleransi pada masyarakat di bidang sosial kemasyarakatan. Desa Wonosari dipilih sebagai lokasi penelitian karena didalamnya terdapat berbagai agama, etnis, ras dan kebudayaan yang beragam dan mencerminkan nilai-nilai multikulturalisme masyarakat Kabupaten Malang. Pada penelitian ini mengambil 12 anggota Forum Kerukunan Umat Beragama, masyarakat, tokoh agama dan aparatur pemerintahan desa sebagai informan dalam proses pengambilan data. Selama 3 bulan penelitian, eneliti melakukan observasi, wawancara, dan dokumentasi terhada informan dalam semua program-program FKUB dan dinamika kehidupan masyarakat terutama yang dilaksanakan di Desa Wonosari Kabupaten Malang. Hasil pengumpulan data yang diperoleh kemudian dianalisis menggunakan model Milles dan Huberman. Teknis analisis tersebut terdiri dari reduksi data, penyajian data, dan verifikasi data (Milles dan Haberman, 2012). Data yang berhasil diperoleh kemudian divalidasi menggunakan teknik triangulasi sumber dan teknik pengumpulan data.

\subsection{Kerangka Teori}

\subsubsection{Persatuan}

Menurut Kaelan (2013, hlm. 142) persatuan mengandung makna bahwa:Sila ketiga Pancasila yaitu 'Persatuan Indonesia' yang terdiri atas dua kata yaitu Persatuan (S) dan Indonesia (ket),jadi inti pokok sila ketiga kata 'persatuan' yang terdiri dari akar kata 'satu'+per -/-an. Maka 'persatuan' secara morfologis berarti suatu hasil dari perbuatan, jadi merupakan nomina. Ditinjau dari sudut dinamikanya pengertian 'persatuan' yaitu suatu proses yang dinamis berdirinya bangsa dan Negara 'Indonesia', yaitu merupakan suatu proses persatuan untuk wilayah, bangsa dan Negara Indonesia. Selanjutnya Darmodiharjo (1991, hal. 42) menyatakan bahwa:

Persatuan Indonesia adalah persatuan bangsa yang mendiami wilayah Indonesia. Bangsa yang mendiami wilayah Indonesia ini bersatu karena didorong untuk mencapai kehidupan kebangsaan yang bebas dalam wadah Negara yang merdeka dan berdaulat. Persatuan Indonesia merupakan faktor yang dinamis dalam kehidupan bangsa Indonesia, bertujuan memajukan kesejahteraan umum, dan mencerdaskan kehidupan bangsa serta ikut mewujudkan perdamaian dunia yang abadi.

Untuk mewujudkan hal tersebut diperlukan suatu pandangan hidup yang diyakini oleh semua warga masyarakat yang mendiam wilayah Indonesia, pandangan hidup tersebut adalah Pancasila yang merupakan pandangan hidup yang di gunakan dan diyakini oleh masyarakat Bangsa Indonesia. Menurut Poespowardjojo (1991, hal. 51) "Salah satu peranan Pancasila yang menonjol sejak permulaan penyelenggaraan Negara Republik Indonesia adalah fungsinya dalam mempersatukan seluruh rakyat Indonesia menjadi bangsa yang berkepribadian dan percaya pada diri sendiri". Selanjutnya Latif (2012, hal. 5) mengungkapkan bahwa "Hakikat Indonesia adalah suatu cita-cita untuk mempersatukan unsur-unsur tradisi dan inovasi serta keragaman etnis, agama, budaya, dan kelas sosial kedalam suatu "botol baru" bernama "Negara-bangsa". Hasrat persatuan itu memang terjadi secara negatif, didorong oleh kehendak menghadapi musuh bersama (Negara kolonial), dan secara positif, tercipta oleh 
HUMANIKA Vol. 23 No.1 (2016) ISSN 1412-9418

Implementasi Semangat Persatuan Pada Masyarakat Multikultural Melalui Agenda Forum Kerukunan

Umat Beragama (Fkub) Kabupaten Malang

Nasrul Wahyu Suryawandan, Endang Danial

hasrat untuk mencapai kebahagiaan bersama".

\subsubsection{Multikulturalisme}

Multikulturalisme berasal dari dua kata; multi (banyak/beragam) dan kultural (budaya atau kebudayaan), yang secara etimologi berarti keberagaman budaya. Budaya yang mesti dipahami, adalah bukan budaya dalam arti sempit, melainkan mesti dipahami sebagai semua dialektika manusia terhadap kehidupannya. Dialektika ini akan melahirkan banyak wajah, seperti sejarah, pemikiran, budaya verbal, bahasa dan lain-lain.

Sejarah munculnya konsep multikulturalisme tidak hanya terdapat pada bangsa Indonesia, naun di Amerika sejarah unculnya konsep multikulturalisme diawali oleh adanya diskriminasi etnis yang kemudian mendorong terbentuknya MCE di negara tersebut. Menurut Writer, 2008, hal. 5) MCE berawal di USA berawal dari pergerakan HAM di akhir 1960-an sebagai macam macam kelompok ethnic yang ditentang dan di konfrontir tekanan yang sangat berat dan ketidak adilan mereka secara sejarah dan berlanjut pada diskriminasi individual, institusional dan structural. Indonesia merupakan negara yang memiliki berbagai etnis, kebudayaan dan agama yang bermacammacam sehingga dirasakan perlu untuk membentuk konsep multikulturalismedalam kehidupan masyarakat.Sedangkan Kymlicka (2011, hal. 13) menyatakan bahwa masyarakat modern semakin sering dihadapkan pada kelompok minoritas yang menuntut pengakuan atas identitas mereka, dan diterimanya budaya mereka. Hal seperti itu sering disebut sebagai tantangan dari "Multikulturalisme". Namun Istilah "Multikultural" mencakup berbagai bentuk pluralism budaya yang berbeda, masingmasing memiliki tantangan sendirisendiri. Ada berbagai cara dimana minoritas menyatu dengan komunitas politik, mulai dari penaklukan dan penjajahan masyarakat yang sebelumnya memerintah sendiri sampai pada imigrasi sukarela perorangan dan keluarga. Perbedaan- perbedaan dalam cara penggabungan itu mempengaruhi sifat dari kelompok minoritas dan bentuk hubungan yang mereka kehendaki dengan masyarakat yang lebih luas.

Seiring berkembangnya tekhnologi, komunikasi dan kemajuan pada bidang transportasi yang meningkatkan mobilitas manusia muncul konsep multikulturalisme yang dikaitkan dengan agama, yakni "multikulturalisme religius" yang menekankan tidak terpisahnya agama dari negara, tidak mentolerir adanya paham, budaya, dan orang-orang yang atheis (Harahap, 2008. Hal 65). Dalam konteks ini, multukulturalisme dipandang sebagai pengayaan terhadap konsep kebudayaan bangsa Indonesia yang majemuk dan mencakup konsep kerukunan umat beragama yang dikembangkan secara nasional. Sedangkan Muzhar dalam Harahap (2007, hal. 28) mengungkapkan bahwa "Multikulturalisme mencakup gagasan, cara pandang, kebijakan, penyikapan dan tindakan, oleh masyarakat suatu Negara, yang majemuk dari segi etnis, budaya, agama dan sebagainya, namun mempunyai cita-cita untuk mengembangkan semangat kebangsaan yang sama dan memmpunyai kebanggaan untuk mempertahankan kemajemukan tersebut "

\subsubsection{Kerukunan Umat beragama}

Menurut Lubis (2005, hlm. 7-8) "Dalam bahasa Inggris disepadankan dengan harmonious atau concord. Dengan demikian, kerukunan berarti kondisi social yang ditandai oleh adanya keselarasan, kecocokan, atau ketidak berselisihan (harmony, concordance). Dalam literatur ilmu sosial, kerukunan diartikan dengan istilah intergrasi (lawan disintegrasi) yang berarti the creation andmaintenance of 
diversified patterns of interactions among outonomous units'. Kerukunan merupakan kondisi dan proses tercipta dan terpeliharannya pola-pola interaksi yang beragam diantara unit-unit (unsure / sub sistem) yang otonom. Kerukunan mencerminkan hubungan timbal balik yang ditandai oleh sikap saling menerima, saling mempercayai, saling menghormati dan menghargai, serta sikap saling memaknai kebersamaan.

Kerukunan tidak hanya di pergunakan dalam konteks pergaulan sehari- hari, Munawar (2005, hlm. 4-5) mengemukakan bahwa "Telah dikemukakan sebelumnya bahwa kata kerukunan hanya dipergunakan dan berlaku dalam dunia pergaulan. Kerukunan antar umat beragama bukan berarti merelatifir agama-agama yang ada dan melebur kepada satu totalitas (sinkretisme agama) dengan menjadikan agama-agama yang ada itu sebagai mazhab dari agama totalitas itu, melainkan sebagai cara atau sarana untuk mempertemukan, mengatur hubungan luar antara orang yang tidak seagama atau antara golongan umat beragama dalam kehidupan social kemasyarakatan". Selanjutnya Muhaimin (2004, hlm. 19) menyatakan bahwa membangun kehidupan umat beragama yang harmonis bukan merupakan agenda yang ringan. Agenda ini harus dijalankan dengan hatihati menginngat agama sangat melibatkan aspek emosi umat, sehingga sebagian mereka lebih cenderung pada "klaim kebenaran" dari pada "mencari kebenaran". Meskipun sejumlah pedoman telah digulirkan, pada umumnya masih sering terjadi gesekan-gesekan ditingkat lapangan, terutama berkaitan dengan penyiaran agama, pembangunan rumah ibadah, perkawinan berbeda agama, bantuan luar negeri, perayaan hari-hari besar keagamaan, kegiatan aliran sempalan, penodaan agama, dan sebagainya.
Menghadapi realitas ini setiap pemeluk agama dituntut agar senantiasa mampu menghayati sekaligus memposisikan diri dalam konteks pluralitas dengan didasari semangat saling menghormati serta menghargai eksistensi agama lain (Ruslani, 2000, hlm.167). Realitas bangsa Indonesia yang terdiri dari berbagai agama mengharuskan masyarakat lebih menghayati dan mampu menempatkan diri melalui nilai kerukunan dan toleransi dalam masyarakat yang plural.

\section{HASIL PENELITIAN DAN PEMBAHASAN}

\subsection{Pemahaman Konsep keragaman, Pluralisme dan Persatuan dari FKUB}

Menurut peneliti konsep-konsep yang dikembangkan oleh Forum Kerukunan antar Umat Beragama Kabupaten Malang meliuti konsep nilai Keragaman, Pluralisme, dan Persatuan, jadi peneliti melakukan wawancara dengan sumber yang bisa dipercaya serta mengerti tentang bagaimana konsep yang dikembangkan oleh FKUB. Konsep pertama yang dikembangkan oleh Forum Kerukunan Umat Beragama Kabupaten Malang dalah keberagaman, keberagaman merupakan suatu keadaan dimana masyarakat Kabupaten Malang tidak terdiri hanya dari satu Agama, satu etnis, satu Kebudayaan dan satu kelompok. Oleh karena itu masyarakat harus mengerti dan memahami bagaimana keadaan masyarakat sekitar yang terdiri dari berbagai suku, agama dan Kebudayaan.

Pluralisme dalam masyarakat Kabupaten Malang diwujudkan dengan adanya penghargaan terhadap individu lain yang memiliki agama, kebudayaan dan etnis berbeda, penghargaan tersebut daat dilihat dari adanya kebersamaan dalam kegiatan doa bersama yang dihadiri 
oleh berbagai agama serta kegiatan kenduri yang melibatkan masyarakat dari berbagai latar belakang agama. Selanjutnya terkait konsep persatuan yang dikembangkan adalah penghayatan dan implementasi nilai persatuan pada masyarakat multikultur di Kabupaten Malang, konsep persatuan yang dikembangkan adalah nggandengne menyambungkan semua elemen masyarakat Kabupaten Malang dengan berbagai latar belakang agama, kebudayaan, keyakinan, golongan dan etnis yang berbeda sehingga dengan menyambungkan dalam konteks komunikasi dapat diwujudkan nilai-nilai persatuan pada masyarakat Kabupaten Malang.

\subsection{Eksistensi Pembentukan FKUB pada Masyarakat Multikultural di Kabupaten Malang}

Sejarah pembentukan Forum Kerukunan Umat Beragama di Kabupaten Malang dimulai dengan adanya penyusunan Peraturan Bersama Menteri (PBM) Nomor 8 \&9 tahun 2006 yang mengatur mengenai tugas dan Fungsi Kepala Daerah dalam rangka menjaga persatuan dan kesatuan pada masyarakat. Berdasarkan Surat Keputusan Bupati Malang mengenai pembentukan Forum Kerukunan Umat Beragama Kabupaten Malang yang menjadi dasar pembentukan FKUB Kabupaten Malang. Pada awal pembentukan FKUB Kabupaten Malang di fasilitasi oleh Badan kesatuan bangsa pollitik dan Kementrian agama di Kabupaten Malang, fasilitas tersebut berupa penentuan anggota dan rapat penentuan kegiatan yang akan dilaksanakan pada Kabupaten Malang.

Keanggotaan FKUB Kabupaten Malang berasal dari Tokoh agama dan akademisi yang merupakan warga masyarakat Kabupaten Malang. Hal tersebut bertujuan agar anggota FKUB dapat beradatasi dengan cepat terhadap dinamika masyarakat dan permasalahan yang timbul pada masyarakat. Penentuan komposisi anggota FKUB Kabupaten Malang menganut prinsip proporisonal, Islam merupakan agama mayoritas masyarakat Kabupaten Malang sehingga anggota dari FKUB mayoritas terdiri dari agama Islam sehingga mampu mewakili aspirasi masyarakat muslim mayoritas di Kabupaten Malang. Kemudian diikuti oleh Kristen, Katholik, Hindu, Budha dan Konghucu.

Penyusunan Kegiatan didasarkan pada kebutuhan nyata masyarakat Kabupaten Malang, yaitu adanya dialog yang membahas mengenai pendirian rumah ibadah, kerukunan masyarakat dalam bersosialisasi, pelaksanaan kegiatan do'a bersama, kendurian, dan kegiatan sosial masyarakat yang rentan menimbulkan gejala-gejala konflik di masyarakat.

\subsection{Program Pelaksanaan dan Keberhasilan FKUB}

Menuruut Peneliti program kegiatan yang dilakukan oleh Forum Kerukunan Umat Beragama Kabupaten Malang meliputi dialog, menampung dan menyalurkan aspirasi masyarakat, sosialisasi perundang-undangan dan pemeliharaan kerukunan pada masyarakat. Kegiatan dialog dilakukan dengan tetap mengambil tema kerukunan dan persatuan dalam masyarakat. FKUB merupakan symbol dari kebersamaan jadi setiap dari kepala dinas itu diadakan dialog masingmasing, dan kemudian tupoksi dari FKUB adalah tokoh masyarakat dan tokoh agama yang diundang kemudian diajak dialog. Pada waktu duduk bersama itu ada sosialisasi peraturan bersama menteri tentang pendirian rumah ibadah, kemudian tinggal program pemerintah kabupaten itu apa, disinergikan dengan program Pemerintah Kabupaten Malang. 
PadaKabupaten Malang yang di bangun disamping dalam hal kebersamaan, itu dalam hal ketika ada riak- riak kecil yang dapat menimbulkan konflik FKUB sudah bereaksi dahulu jadi setiap tokoh agama pro aktif. Kalau seumpama dicontohkan di turen ini ada yang akan mendirikan gereja, karena izinnya belum lengkap akan menimbulkan masalah.Adapun, keinginan dari masyarakat Kabupaten Malang yang menginginkan terciptanya toleransi ketka mengadakan kerja bakti dan kegiatan doa bersama yang dilakukan oleh berbagai pemeluk agama untuk kesejahteraan bersama. Dari adanya keinginan masyarakat tersebut FKUB memberikan sosialisasi pada masyarakat untuk tidak mengedepankan sikap fanatisme kelompok dan agama dalam pergaulan dan sosialisasi dalam masyarakat sehigga dengan adanya perbedaan pada masyarakat Kabupaten Malang akan tetap terjaga nilai persatuan yang diimplementasikan melalui adanya kegiatan kenduri, pertunjukan lintas kebudayaan, perayaan hari besar keagamaan dengan damai dan kerjasama dalam bidang sosial religius yang harmonis dengan adanya gerak jalan lintas agama sebagai wadah komunikasi antar umat beragama di Kabupaten Malang.

\subsection{Faktor Determinan yang Dihadapi oleh FKUB}

Faktor yang mendukung salah satunya adalah dukungan moril dari semua pihak, secara materiil adalah pemerintah Kabupaten Malang yang merupakan pihak yang memberikan anggaran pada FKUB terkait dengan pembiayaan operasional kegiatan yang dilaksanakan pada masyarakat. Dukungan moril datang dari pihak-pihak yang ikut membangtu terselenggaranya kegiatan FKUB, seperti Kemenag, Bakesbangpol, Bintal, pemerintah desa dan BKKBN. Berbagai kegiatan dan program yang dilakukan oleh
FKUB tidak mungkin dapat terselenggara dengan baik tanpa adanya kerjasama dari berbagai pihak yang turut memberikan bantuan dan memfasilitasi dalam berbagai hal. Faktor pendukung dari internal organisasi adalah adanya kesadaran pengurus, pengurus FKUB tidak memerlukan undangan untuk datang dalam dialog namun hanya dengan telfon dan memanfaatkan sosial media anggota FKUB datang untuk menghadiri acara. Kesadaran dan peran aktif pengurus merupakan faktor yang sangat penting dalam organisasi guna menunjang terselenggaranya kegiatan yang akan dilaksanakan di masyarakat maupun dalam agenda-agenda yang berkaitan dengan koordinasi dengan pihak-pihak yang terkait. Adanya respon positif dari mmasyarakat terkait dengan adanya FKUB di asyarakat merupakan modal utama terkait dengan eksistensi FKUB di masyarakat, masyarakat menganggap perlu adanya FKUB untuk menengahi dan memfasilitasi konflik-konflik dalam masyarakat sekaligus sebagai pemelihara kerukunan hidup beragama dalam masyarakat.

Faktor Penghambat dalam proses kegiatan FKUB adalah pada proses penghimpunan informasi yang kurang menyeluruh, informan yang diberikan tugas untuk mencari dan menghimpun informasi dalam masyarakat tidak merata. Dari informasi yang kurang menyeluruh tersebut menghambat proses kegiatan yang dilakukan oleh FKUB, baik dalam menghimpun penyebab konflik yang terjadi dalam masyarakat maupun kurang mengertinya anggota yang diberikan tugas untuk mensosialisasikan rencana program yang akan dilaksakan dalam menghimpun dan mengumpulkan berbagai elemen masyarakat yang akan diikutsertakan dalam kegiatan tersebut. Kendala tersebut muncul karena kesalah fahaman dengan maksud yang diinginkan oleh FKUB yang terdapat pada berbagai tingkatan, kesalah 
fahaman tersebut dapat terjadi pada anggota FKUB, pemerintah desa, tokoh agama dan organisasi yang bekerja sama dengan FKUB.Kendala yang dihadapi selanjutnya adalah sikap fanatisme dari masyarakat yang menganggap bahwa yang di yakini dirinya dan kelompok adalah hal yang memiliki nilai yang paling benar, sehingga cenderung memiliki sikap intolransi dalam masyarakat dan kurang menghargai adanya perbedaan dalam segi ideologi, latar belakang agama, etnis dan golongan yang berbeda.

\section{PEMBAHASAN}

\subsection{Pemahaman Konsep Keragaman,} Pluralisme dan Persatuan dari FKUB

Hasil penelitian menunjukkan bahwa efektivitas FKUB Kabupaten Malang dilaksanakan dengan baik melalui berbagai kegiatan yang dilakukan dalam masyarakat dengan menanamkan nilainilai persatuan dan menyelesaikan konflik dengan mengedepankan azas musyawarah dan dialog dan menggunakan pendekatan humanistik sebagai salah satu metode dalam meredam konflik dan fanatisme pada masyarakat Kabupaten Malang. Menurut Sefulloh (2009: 6) setidaknya ada tiga istilah yang sering digunakan dalam menggambarkan keanekaragaman atau keberagaman yang terjadi dalam masyarakat, yaitu: keragaman (diversity), pluralitas (plurality), dan mulitikultur (multicultural). Ketiganya memang menunjukkan adanya ketidaktunggalan (lebih dari satu), namun masing-masing merepresentasikan hal yang berbeda. Diversity menunjukkan keadaan yang heterogen, di mana satu dengan yang lainnya tidak dapat disamakan.

Diantara berbagai keanekaragaman model penyampaian tugas, bentuk pedagogik yang paling utama adalah sebuah model yang multicultural yang menekankan toleransi terhadap perbedaan individu dan kelompok, memahami berbagai macam norma budaya, dan stategi komunikasi antar budaya (Gibson 2007: 155). Selanjutnya Parekh (2000: 3) memetakan tiga bentuk keragaman dalam masyarakat modern yang dapat dilihat juga sebagai kemunculan keragaman lintas batas. Pertama, adalah keragaman subkultur yang merupakan keragaman identitas karena munculnya subkultur-subkultur baru di luar kultur dominan, sehingga walaupun sebagian besar anggota masyarakat hidup dalam budaya tertentu, sebagian kecil lainnya memiliki keyakinan dan praktik hidup khusus atau relatif berbeda dengan cara hidup orang pada umumnya, misalnya saja kelompok gay dan lesbian. Kedua, adalah keragaman perspektif yang muncul bila terdapat sebagian anggota masyarakat yang kritis terhadap prinsip-prinsip atau nilai-nilai budaya dominan yang dianggap tidak ideal dan mencari jalan alternatif baru untuk memperbaiki keadaan. Keragaman ini biasanya muncul dari kalangan intelektual, misalnya para feminis atau environmentalist. Ketiga, adalah keragaman komunal yang muncul bila terdapat anggota-anggota masyarakat yang hidup dalam kelompok-kelompok yang terorganisir dengan baik dan berbagi sistem dan praktik kehidupan tertentu yang berbeda dari masyarakat pada umumnya. Misalnya saja, kelompokkelompok keagamaan baru, kelompok etnis atau imigran yang hidup di wilayah tertentu".

Kerukunan hidup umat beragama bukan berarti merelatifir agama-agama yang ada dengan melebur kepada satu totalitas (sinkretisme agama) dengan menjadikan agama- agama yang ada itu sebagai unsur dari agama totalitas itu. Dengan kerukunan dimaksudkan agar terbina dan terpeligara hubungan baik dalam pergaulan antara warganegara yang berlainan agama. Urgensi kerukunan adalah mewujudkan kesatuan pandangan 
dan kesatuan sikap, guna melahirkan kesatuan perbuatan dan tindakan serta tanggung jawab bersama, sehingga tidak ada pihak yang melepaskan diri dari tanggung jawab atau menyalahkan pihak lain. Dengan kerukunan umat beragama menyadari bahwa masyarakat dan negara adalah milik bersama dan menjadi tanggung jawab bersama untuk memeliharanya (Suryana 2011: 135).

Keberagaman agama dan kebudayaan yang terdapat pada masyarakat Kabupaten Malang merupakan hasil dari adanya kemajemukan penduduk dan adanya berbagai perpindahan penduduk yang sekaligus membawa paham agama dan kebudayaan dari daerah asal. Seketika keberadaan kebudayaan tersebut diakui oleh masyarakat sebagai keberagaman kultur budaya maka akan menumbuhkan sebuah kesadaran masyarakat akan nilai persatuaan dalam skala nasional, selama itu tidak mengancam dan membatasi eksistensi budaya dan kearifan lokal yang ada.

\subsection{Eksistensi Pembentukan FKUB pada Masyarakat Multikultural di Kabupaten Malang}

Studi terbaru dari keterlibatan sipil dengan etnis lain telah berusaha untuk memikirkan kembali dasar multikulturalisme liberal dengan menempatkan migran di sebaya, tidak diferensial, waktu. Berdasarkan studi etnografi migran subcontinental (Indo-kei) di Jepang kontemporer (Vij, 2012: 3). Keterlibatan sipil merupakan salah satu konsep dalam menyusun dan mengembangkan nilai multikulturalisme dalam sebuah negara sehingga korelasi antara pemerintah dan warganegara akan terjalin dengan baik dan membentuk sebuah keharmonisan.Pemerintah dan masyarakat dapat di ibaratkan sebagai sebuah tim yang saling bekerjasama dalam memelihara kerukunan dan persatuan pada masyarakat Kabupaten Malang, sehingga diperlukan korelasi dan kerjasama antara berbagai pihak dalam struktur pemerintahan serta masyarakat. Lesilolo (2012: 84) menyatakan bahwa "Kepimimpinan bukanlah merupakan apa yang anda lakukan terhadap orang lain, melainkan apa yang anda lakukan bersama orang lain". Dalam tim, kita tidak bekerja sendiri. Masing-masing anggota mengemban tugas masing-masing dan bekerja mandiri namun masih bergantungdan berkesinambungan satu samalainnya.Dalamtimdibutuhkankerjasam adankekompakanyangakanmenjadikan tim tersebutkuatdansolid.

Keterkaitan antar individu dalam kelompok merupakan sebuah syarat mutlak untuk dapat menjalankan sebuah organisasi. Hal tersebut dapat dilihat dalam keanggotaan FKUB Kabupaten Malang yang dalam pemilihan anggota didasarkan pada realitas masyarakat serta jumlah yang proporsional, sehingga dapat mewakili aspirasi masyarakat. Menurut Asiati (2014: 2) menyatakan bahwa "Sesuaimandatnya, kepengurusan FKUB dijabat berdasarkan keterwakilan jumlah pemeluk agama. Jika cara pandang mereka masih memihak, tak mustahil konflik yang terjadi diselesaikan secara tidak seimbang, apalagi jika itu menyangkut kepentingan kelompok mayoritas. Baik yang mayoritas maupun yang minoritas, seharusnya tetap memegang orientasi kepentingan bersama, bukan kepentingan kelompoknya”.

\subsection{Program Pelaksanaan dan \\ Keberhasilan FKUB}

Interaksi diskursif mewujudmenjadi dialog antar budaya dan kepercayaan. Pertukaran informasi mengenai budaya dan kepercayaan antara etnis tempatan dengan etnis Tionghoa membuka kesadaran kesejarahan (Yusar, 2015: 13). Interaksi- 
interaksi berbagai pihak merupakan hal vital yang harus selalu dikembangkan dalam kehidupan sosial masyarakat untuk meminimalisir kesalafahaman dalam interaksi sosial. Menurut Hamzah dan Markana (2013: 20) masyarakat terkadang mengabaikan nilai-nilai kebersamaan dalam beragama. Padahal dalam beragama harus dapat mengimplementasikan nilainilai kemanusiaan; menghormati hak asasi orang lain, peduli terhadap orang lain. Pradigma dialogis-persuasif mengedepankan dialog dan cara-cara damai dalam melihat perselisihan dan perbedaan pemahaman keagamaan masyarakat. Dialog dengan cara damai merupakan salah satu solusi dalam menyelesaikan berbagai konflik yang muncul dalam masyarakat. Dialog mutlak diperlukan dalam menghadapi masyarakat yang beragam baik beragam dalam hal agama, etnis dan budaya.Alternative Dispute Resolution (ADR), cara ini dikenal dengan istilah musyawarah untuk mufakat. Merupakan alternatif penyelesaian konflik dengan menggunakan pihak ketiga yang berperan di sekitar mereka. Bisa dari tokoh masyarakat juga dari aparat (Unwanullah, 2012: 58). Penggunaan metode dialog oleh FKUB dimaksudkan untuk menemukan titik temu mengenai berbagai dinamika sosial kemasyarakat yang sedang terjadi pada lingkup desa dan nasional, sebagai bahan perbandingan dan pembelajaran untuk dapat mengambil kesimpulan dan pemecahan secara langsung dengan masyarakat.

Kegiatan menampung dan menyalurkan aspirasi masyarakat merupakan salah satu agenda dimana FKUB Kabupaten Malang turun pada masyarakat untuk menghimun informasi dan selanjutnya menyampaikan hal tersebut pada pemerintah. Kegiatan tersebut meliputi berbagai permasalahan dalam mendirikan rumah ibadah, keinginan masyarakat untuk tetap mempertahankan dan melestarikan nilai- nilai budaya yang bersifat kedaerahan dalam menghadapi berbagai tantangan modernisasi dan merebaknya budaya barat. Sehingga diperlukan tindakan dari pemerintah untuk tetap menjaga nilai-nilai budaya dan kearifan local pada masyarakat Kabupaten Malang.Menurut Syahril (2013: 304) ketika ide dan gagasan yang berserakan di benak individu-individu diadu dan digesekkan dalam forum permusyawaratan, maka akan keluar percikan-percikan ide baru yang lebih solutif dan konstruktif. Serumit apapun suatu persoalan, pasti dapat dicari solusinya melalui musyawarah. Pada substansinya, tak ada persoalan apapun yang tidak ada solusi. Dengan musyawarah, kebuntuan akan terbuka lebar, di samping stagnasi akan tercairkan, dan berikutnya perseteruan akan dapat di damaikan, pada akhirnya perbedaan akan dapat diintegrasikan.

Kegiatan mensosialisasikan perundang-undangan terutama Peraturan bersama Menteri Agama dan Menteri Dalam Negeridilakukan dengan membagikan Buku PBM kepada tokoh agama, dan aparatur pemerintahan desa. Kemudian disertai dengan penjelasan dalam pasal-pasal mengenai ketentuan dan penjabaran tersebut. Meskipun memiliki buku peraturan namun jika masyarakat tidak memahami secara baik maka akan percuma, sehingga dengan pembagian buku tersebut harus disertai dengan penjelasan dan diskusi untuk mengetahui masksud dan tujuan adanya peraturan tersebut. Ibrahim (2008: 117) menyatakan "Sikap saling menerima, menghargai nilai, budaya, keyakinan yang berbeda tidak otomatis akan berkembang sendiri. Apalagi karena dalam diri seseorang ada kecenderungan untuk mengharapkan orang lain menjadi seperti dirinya. Sikap saling menerima dan menghargai akan cepat berkembang bila dilatihkan dan dididikkan pada generasi muda dalam sistem pendidikan nasional". 
Kasus pada masyarakat Kabupaten Malang dikenal adanya istilah selamatan/ kenduri yang diadakan di rumah warga ataupun dilaksanakan di Mushola ataupun masjid tersekat, sehingga jumlah masjid ataupun tempat ibadah yang ada dalam masyarakat harus diatur sedemikian rupa untuk menghindari adanya perpecahan dalam masyarakat terkait dengan adanya rumah Ibadah yang saling berdekatan. Seperti yang terjadi di Desa Wonosari Kabupaten Malang, adanya rumah ibadah yang saling berdekatan mendapatkan perhatian khusus dari FKUB Kabupaten Malang untuk bagaimana menjaga keharmonisan kehdupan keberagamaan agama masyarakat di desa tersebut.

\subsection{Faktor Determinan yang Dihadapi oleh FKUB}

Organisasi adalah suatu kesatuan sosial yang telah terkoordinasi secara sadar dengan adanya sebuah batasan yang relatif dan dapat diidentifikasi serta bekerja berdasarkan yang relatif secara terusmenerus agar dapat mencapai tujuan bersama (Robbins, 2002: 48).Dukungan dan kerjadama FKUB Kabupaten Malang dengan Lembaga Swadaya Masyarakat, Bakesbangpol, Bina mental dan Kemenag merupakan modal penting FKUB dalam melaksanakan agenda- agenda yang akan dilaksanakan di Kabupaten Malang. Korelasi dan kerjasama yang kuat dari berbagai pihak akan memberikan motivasi dan dorongan mental kepada angota FKUB untuk dapat terus melaksanakan tugas dalam memelihara kerukunan dan persatuan di Kabupaten Malang.Keterbukaan dalam menghadapi setiap permasalahan yang ada pada masyarakat dan sebuah organisasi merupakan syarat mutlak untuk membentuk suatu masyarakat dan organisasi yang baik, begitu juga dengan adanya keterbukaan dari masyarakat akan mendukung terjalinnya komunikasi yang baik dan selanjutnya akan berdampak pada adanya kerjasama serta korelasi yang baik antara masyarakat dan FKUB. Misrawi (2013: 203) menyatakan bahwa Adanya keterbukaan untuk melihat kelompok lain sebagai warga negara dan makhluk Tuhan yang mempunyai kesempatan sama di depan hukum (awarness). Keterbukaan tersebut merupakan konsekuensi dari tumbuhnya kesadaran perihal pentingnya multikulturalisme, terutama dalam rangka membangun demokrasi yang berkeadilan dan berkeadaban. Tingkatan ini lebih baik dari koeksistensi, karena telah menumbuhkan keterbukaan terhadap kelompok lain.

Kendala yang muncul dari dalan internal organisasi berikutnya adalah mengenai adanya anggota yang membawa visi dan misi kelompok dalam forum, sehingga cenderung lebih memberikan hambatan dalam menanamkan nilai- nilai toleransi pada masyarakat. Pembawaan misi tersebut adalah sebagai salah satu maksud untuk memperjuangkan anggota kelompok atau golongannya meskipun minoritas namun menginginkan hal yang lebih dari pada peraturan yang semestinya. Hal tersebut bertentanggan dengan apa yang telah ditentukan dalam ketentuan peraturan dan peraturan bersama Menteri agama dan menteri dalam negeri sehingga akan menimbulkan gejolak dalam struktur organisasi.Adanya konflik yang terjadi dalam konteks Indonesia, akar penyebabnya memang cukup beragam. Ada faktor kesenjangan ekonomi, perseteruan politik, perebutan kekuasaan atau persaingan antar agama. Namun demikian, dari sebagian besar konflik dan kekerasan yang ada "agama" dinilai menjadi salah satu faktor yang ikut andil sebagai pemicu, agama boleh dibilang sebagai unsur sosial yang paling sensitif (Naim dalam Hadi 2014: 253). 
HUMANIKA Vol. 23 No.1 (2016) ISSN 1412-9418

Implementasi Semangat Persatuan Pada Masyarakat Multikultural Melalui Agenda Forum Kerukunan Umat Beragama (Fkub) Kabupaten Malang

Nasrul Wahyu Suryawandan, Endang Danial

\section{SIMPULAN}

Berdasarkan sejumlah temuan penelitian yang dipaparkan pada pembahasan sebelumnya maka secara umum dapat disimpulkan bahwa dalam menerapkan, menjaga dan memelihara nilai keberagaman, pluralisme dan persatuan pada masyarakat Kabupaten Malang yang terdiri dari latar belakang agama Islam, Kristen Hindu, Budha dan Konghucu Forum Kerukunan Umat Beragama Kabupaten Malang melaksanakan berbagai agenda kegiatan dialog, menampung dan menyalurkan aspirasi masyarakat, sosialisasi perundangundangan, dan memberdayakan masyarakat untuk tetap menjaga kerukunan dan persatuan pada masyarakat Kabupaten Malang. Kegiatan-kegiatan pada konteks budaya merupakan salah satu kegiatan yang melibatkan masyarakat dari berbagai pemeluk agama berbeda, seperti do'a bersama, kendurian, selamatan, tayub dan peringatan satu syuro yang dimeriahkan dengan adanya pentas send an gelar budaya dari berbagai daerah di Kabupaten Malang. Dengan adanya kegiatan tersebut masyarakat Kabupaten Malang lebih memahami dan mengimplementasikan semangat persatuan dan menjunjung tinggi keberagaman yang ada pada kehidupan sosial masyarakat yang terdri dari multi agama, multi etnis dan berbagai suku yang mendiami Kabupaten Malang secara umum.

\section{Saran}

Saran bagi masyarakat Kabupaten Malang adalah agar dapat lebih menghargai berbagai perbedaan yang ada dalam struktur sosial masyarakat untuk tetap dapat menjaga kerukunan dan persatuan dan kesatuan serta keharmonisan hidup dalam masyarakat. Sikap toleransi dan keterbukaan serta komitmen untuk menyelesaikan setiap permasalahan dengan duduk bersama dan melakukan musyawarah merupakan salah satu jalan dalam menjaga nilai- nilai tersebut.Bagi peneliti selanjutnya untuk dapat mengembangkan penelitian dalam konteks sosial masyarakat pada berbagai daerah di Indonesia melalui research \& development. Serta bagaimana alternative dalam menggali dan menumbuhkan kesadaran masyarakat untuk menjaga kerukunan dan persatuan bangsa Indonesia. 
HUMANIKA Vol. 23 No. 1 (2016) ISSN 1412-9418

Implementasi Semangat Persatuan Pada Masyarakat Multikultural Melalui Agenda Forum Kerukunan Umat Beragama (Fkub) Kabupaten Malang

Nasrul Wahyu Suryawandan, Endang Danial

\section{DAFTAR PUSTAKA}

Azra, Azyumardi. (1999). Konteks

Berteologi di Indonesia

Pengalaman Islam. Jakarta:

Paramadina,

Abrams, L S; Gibson, P. (2007). Teaching Notes Multicultural education; Teaching White Privilege in The Social Work Curiculum. Journal of Social Work Education

Asiati. (2014). Optimalisasi Peran FKUB dalam Menciptakan Toleransi Beragama di Kota Pekanbaru. Media Komunikasi Umat Bergama, Vol.6, No.2 JuliDesember 2014

Budimansyah, D. (2012). Perencanaan Pembelajaran Berbasis Karakter. Bandung: Widya Aksara pers

Darmodiharjo, Darji. (1991). Santiaji Pancasila. Surabaya: Usaha Nasional

Hadi A, S. (2014). Problem Multikulturalisme dalam Pendidikan Agama Islam. Jurnal At-Ta'dib Vol.9, No. 2, Desember 2014

Harahap, A, Rifai. (2004). Multikulturalisme dan Penerapannya dalam Pemeliharaan Kerukunan antar Umat Beragama

Ibrahim. R. (2008). Pendidikan Multikultural: Upaya Meminimalisir Konflik dalam Era Pluralitas Agama. Jurnal Pendidikan Islam El- Tarbawi NO. 1. VOL. I. 2008

Kaelan. (2013). Negara Kebangsaan Pancasila: Kultural, Historis,
Filosofis, Yuridis dan Akulturasinya. Yogyakarta: Paradigma

Kymlicka, Will. (2011). Kewargaan Multikultural. Jakarta: Pustaka LP3ES Indonesia

Latif. Y. (2011). Negara

Paripurna:Historisitas, Rasionalitas, Aktualitas Pancasila. Gramedia Pustaka Utama

Lesilolo.H. J. (2012). Kepemipinan Transformasional dalam Rekonstruksi Agama di Indonesia.Jurnal Pembangunan Pendidikan: Fondasi dan Aplikasi. Volume 1, Nomor 1, Juni, 2012

Lubis, Ridwan. (2005). Cetak Biru Peran Agama. Jakarta: Puslitbang

Muchali. I. (2013). Peace Education dan Deradikalisasi Agama.Jurnal Pendidikan Islam: Volume II, Nomor 1, Juni 2013

Miles, M. B., dan Huberman, A. M. 2012. Analisis data kualitatif: Buku sumber tentang metode-metode baru. Jakarta: Universitas Indonesia Press.

Misrawi. Z. (2013). Kesadaran Multikultural dan Deradikalisasi Pendidikan Islam: Pengalaman Bhinneka Tunggal Ika dan Qabul Al-akhar. Jurnal Pendidikan Islam: Volume II, Nomor 1, Juni 2013

Munawar, S Agil. Fikih Hubungan Antar Umat Beragama. Jakarta, Ciputat Press, 2005 
HUMANIKA Vol. 23 No.1 (2016) ISSN 1412-9418

Implementasi Semangat Persatuan Pada Masyarakat Multikultural Melalui Agenda Forum Kerukunan Umat Beragama (Fkub) Kabupaten Malang

Nasrul Wahyu Suryawandan, Endang Danial

Octaviani. L. (2013). Model Pendidikan Multikultural di SMA Taruna Nusantara Magelang. Jurnal Komunitas 5 Januari 2013

Parekh, Bihku. 2000. Rethinking Multiculturalism. New York: Palgrave McMillan.

Robbins, Stephen P, (2002). Prinsipprinsip Perilaku Organisasi, PT. Erlangga, Jakarta

Saefulloh. A. (2009). Membaca "Paradigma" Pendidikan dalam Bingkai Multikulturalisme. Jurnal Pemikiran alternatif Kependidikan Vol. 14|No. 3|Sep-Des 2009

Suryana, T. (2011). Konsep dan Aktualisasi Kerukunan antar Umat Beragama .Jurnal Pendidikan Agama Islam- ta'lim Vol. 9 No. 2 2011

Susanto. E. (2006). Pluralitas Agama: Meretas Toleransi Berbasis Multikulturalisme Pendidikan Agama. Tadris Vol 1 No 12006.

Syahril, S. (2013). Integrasi Islam dan Multikulturalisme: Perspektif Normatif dan Historis. Analisis,
Volume XIII, Nomor 2, Desemberi 2013

Unwanullah. A.

(2012).TransformasiPendidikanunt uk Mengatasi Konflik Masyarakat dalam Perspektif Multikultural. Jurnal Pembangunan Pendidikan: Fondasi dan Aplikasi. Volume 1, Nomor 1, Juni 2012

Vij. R. (2012). Temporality, Civic Engagement, and Alterity: Indo-Kei in Contemporary Japan. Alternatives: Global, Local, Political 37(1) 3-29 Januari 2012

Writer, J H. (2008). Unmasking, exposing, and controling: critical race theory, tribal critcal race theory and multicultural education. International Journal of Multicultural Education. Volume 10 nomor 2

Yusar, (2015). Ruang Publik sebagai Pendidikan kesaran Multikulturalisme. Edutech, Tahun 14, Vol.1, No.1, Februari 2015. 